\title{
JUURNAL_RU
}

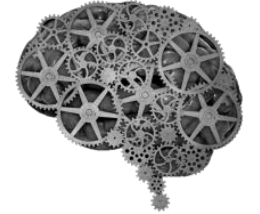

COMPANY GROUP "INTELLEKT"

\author{
Семёнов И.А., Ульянов Б.А., Фереферов М.Ю. \\ Ангарский государственный технический университет \\ Ангарск, Россия
}

doi: 10.18411/lj2016-7-1-18

idsp 000001: lj2016-16-1-18

\section{Исследование влияния механических вибраций на процесс массоотдачи вблизи твердой поверхности}

Исследования в области тепло- и массообмена занимают одно из ключевых значений в разных отраслях технических наук и, в частности, в химической технологии. При постановке синтеза продуктов в рамках лаборатории данные процессы носят вспомогательный характер и остаются на заднем плане при исследовании самого химического превращения. Однако при переходе к промышленным масштабам вопросы эффективности тепло- и массообменных процессов выходят на передний план, определяя принципиальную возможность реализации химической технологии на практике, конструктивные особенности и стоимость технологического оборудования, а также энергопотребление промышленной установки в целом. В этой связи исследования и разработки, направленные на совершенствование технологического оборудования за счет увеличения скорости протекающих процессов переноса тепла и массы, остаются важными и актуальными.

Одним из способов интенсификации процессов тепло- и массообмена в жидкостях и газах является воздействие на среду колебаний различной частоты [1]. Этому направлению в исследованиях посвящено огромное количество научных трудов, причем интерес к рассматриваемой теме остается и по настоящий момент времени.

До сих пор поиску возможностей применения вибрационных и ультразвуковых технологий на промышленном технологическом оборудовании 
уделяется пристальное внимание. Однако внедрение подобных технических устройств имеет свои проблемы и нюансы, которые решаются путем проведения фундаментальных исследований элементарных актов переноса тепла и массы под воздействием колебаний на передающую среду [2].

В настоящий момент времени экспериментально доказано существенное увеличение эффективности тепло- и массоотдачи у вибрирующей твердой поверхности [1]. Кроме того отмечается, что скорость процессов зависит от параметров вибраций, свойств передающеей среды, способов их наложений и многих других факторов. В этой связи в рамках проделанной нами научноисследовательской работы изучался элементарный акт переноса вещества от вибрирующей твердой поверхности в объем жидкой среды [3, 4].

На этапе теоретических изысканий при помощи численных методов моделировался процесс затухания гидродинамических волн в сплошной среде, вызванных колебаниями твердой плоской поверхности. Расчеты показали, что изначально синусоидальный профиль колебаний при распространении в толще жидкости в силу нелинейности дифференциальных уравнений гидродинамики принимал «пилообразный» вид. Возникающие при этом вязкостные напряжения гасили колебания среды, приводя к образованию устойчивого потока жидкости, перпендикулярно направленного от колеблющейся поверхности. Скорость образующегося результирующего потока жидкости прямопропорциональна колебательной скорости поверхности. В рамках исследований теоретически было показано, что характер распространяющихся колебаний определяется колебательным числом Рейнольдса (Re):

$$
\mathrm{Re}=\mathrm{fA} 2 \rho / \mu,(1)
$$

где $\mathrm{f}$ - частота колебаний плоской поверхности, Гц; А - амплитуда колебаний, м; $\rho$ - плотность среды, кг/м3; $\mu$ - коэффициент динамической вязкости среды, Па·с.

При малых значениях числа $\operatorname{Re}$ колебания пластины не образуют результирующего потока среды и, как следствие, не способны интенсифицировать процесс переноса тепла и массы. Устойчивый поток жидкости способен образовываться при умеренных и больших значениях числа Re. В этой связи можно предположить, что имеется некоторое критическое значение числа Re, при котором интенсификация процессов тепло- и 
массообмена становится возможной. Данные критический уровень был определен в ходе экспериментальных исследований колебаний плоского диска в воде и численно составил 0,62 $\pm 0,04$ [3]. Визуальное наблюдение за процессом показало аналогию гидродинамической картины потока, вызванного колебаниями, с движение среды под воздействием естественной конвекцией от нагретой горизонтально-расположенной плоской поверхности.

На следующем этапе исследований исследовалось влияние колебаний плоской поверхности на процесс массотдачи в воде [4]. Для этого изготавливалась серия экспериментальных образцов, представлявших собой отшлифованную с одной стороны плоскую поверхность кристалла медного купороса. Именно этой стороной кристалл соприкасался с водой и на него накладывались вибрации $\mathrm{c}$ частотой до 100 Гц при помощи электродинамического преобразователя. Принципиальная схема экспериментальной установки представлена на рисунке 1.

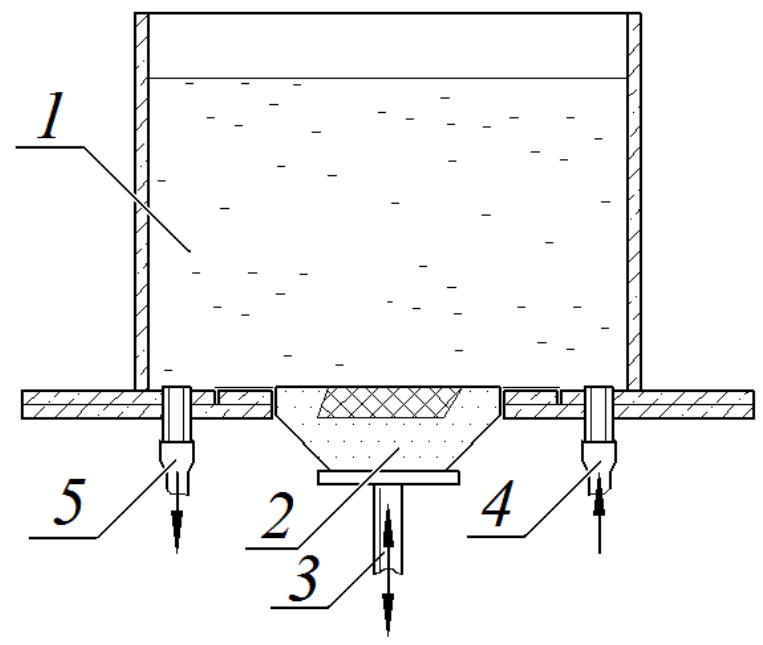

Рисунок 1. Экспериментальная установка

В ходе экспериментов в дно кюветы 1 через гибкую резиновую диафрагму устанавливался экспериментальный образец 2 с отшлифованной поверхностью кристалла медного купороса. Нижней частью образец крепился на шток 3, подсоединяемый к источнику вибраций. Кювета через штуцер 4 заполнялась водой, и образец 2 приводился в движение. В ходе экспериментов частота колебаний варьировалась от 40 Гц до 100 Гц, а амплитуда - от 0,1 мм до 1,0 мм. Точное измерение параметров колебаний проводилось при помощи акселерометра CQ7-3728. Через определенное время эксперимент прекращался, образованный водный раствор медного купороса сливался через штуцер 5, а его 
концентрация определялась при помощи фотоколориметра КФО-У4.2. По массе растворенного медного купороса оценивался коэффициент массоотдачи процесса.

Результаты экспериментов позволили определить критериальное уравнение для оценки скорости массообмена. В качественном плане полученные данные подтвердили прямопорциональность коэффициента массоотдачи от колебательной скорости твердой поверхности.

Исследования выполнены при финансовой поддержке Российского фонда фундаментальных исследований (проект № 16-38-00195).

\section{Литература:}

1. Новицкий Б.Г. Применение акустических колебаний в химикотехнологических процессах. М.: Химия, 1983.

2. Семёнов И.А., Ульянов Б.А., Кулов Н.Н. Влияние ультразвука на растворение углекислого газа в воде // Теоретические основы химической технологии. 2011. Т. 45. № 1. С. 23-27.

3. Семёнов И.А., Ульянов Б.А., Кулов Н.Н. Исследование течений жидкости, возникающих при вибрациях плоской поверхности // Теоретические основы химической технологии. 2013. Т. 47. № 4. С. 379-385.

4. Семёнов И.А., Ульянов Б.А., Кулов Н.Н. Экспериментальная оценка влияния колебаний на скорость массоотдачи от плоской поверхности // Теоретические основы химической технологии. 2016. Т. 50. № 3. С. 239244. 